\title{
Effects of Dependence of Tramadol, Diazepam and Their Combination on the Brain of Albino Rats: Biochemical, Histological and Immunohistochemical Study
}

\author{
Samy Mustafa Badawy, Samy Abd EL Hady Hammad, Safaa Abed El Zaher \\ Amin, Azza Wagih Zanaty, Reham Hassan Mohamed' and Hayam Abed El \\ Samie Aiad ${ }^{2}$
}

${ }^{1}$ Department of Forensic Medicine and Clinical Toxicology

2 Department of Pathology

Faculty of Medicine, Menoufia University, Menofia, Egypt

\begin{abstract}
Introduction: Nowadays tramadol is the most common drug of abuse. Egyptian surveys found a gradual increase in the use of tramadol among Egyptians. It has been associated with a wide range of drug abuse such as benzodiazepines. Aim of the work: This study aimed to evaluate the effects of dependence of tramadol, diazepam, and their combination on biochemical, histopathological and immunohistochemical changes of brain of adult albino rats. Material and Methods: Forty adult male albino rats were divided into four equal groups as follows: Group I (control) received $1 \mathrm{ml}$ normal saline $(0.9 \% \mathrm{NaCl})$ once orally for one month. Group II (tramadol dependent) received increasing therapeutic doses of tramadol orally for one month, Group III (diazepam dependent) received increasing therapeutic doses of diazepam orally for one month, Group IV (tramadol and diazepam dependent) received increasing therapeutic doses of tramadol and diazepam orally for one month. Blood samples were collected from all groups for evaluation of serum cortisol level. Brain was excised for biochemical, histopathological and immunohistolochemical studies. Results: Compared to the control group, serum cortisol level was significantly decreased in tramadol dependent and combined tramadol and diazepam dependent groups. In all experimental dependent groups, brain cholinesterase level was not changed and the brain showed histopathological and immunohistochemical changes Conclusion and recommendation: Tramadol or diazepam dependence for long time affects the brain cells and the combination of both of them leads to more neurotoxic effect. Therefore it is recommended that tramadol or diazepam should be taken only with the prescription of doctor and self medication of these drugs may be hazardous.

Keywords Tramadol, diazepam, brain, dependence.
\end{abstract}

\section{Introduction}

$\mathrm{D}$ rug abuse is always associated with medical hazards, it causes damage to the nervous system, sudden mood changes, deterioration of the immune system, nervous breakdown, and many other side effects. Approximately 50 percent of persons with a substance use disorder have had a co-occurring mental disorder in their life time (Kessler et al., 1996; Amr et al., 2014).

Tramadol is a synthetic analog of codeine with both opioid and monoamine reuptake inhibitor effects. It is a pure opioid agonist, but its affinity for the $\mu$ receptor is weak, being tenfold less than that of codeine. Analgesia results from its inhibition of the reuptake of norepinephrine and serotonin, endogenous neurotransmitters that modulate pain (Wang et al., 2009).

Tramadol, despite being classified with other opioids, it is an atypical member of this group. It generally has fewer side effects and better tolerability than oral nonsteroidal anti-inflammatory drugs (NSAIDs) or traditional opioids (Babalonisa et al., 2013).

Tramadol can cause psychological and physical dependence similar to that of other opiates (Lanier et al., 2010). Repeated tramadol administration might lead to the accumulation of toxic metabolites in the body, increase the risk for pharmacokinetic interactions, and/or decrease the 
clearance of tramadol, thus increasing its potential for toxicity (Shadnia et al., 2008).

Benzodiazepines (BZDs) are sedativehypnotic agents commonly used for a variety of situations that include seizure control, anxiety, alcohol withdrawal, insomnia, control of drug-associated agitation, as muscle relaxants, and as preanaesthetic agents (Abdelmajeed, 2009). Because of their widespread use, these drugs have propensity for abuse either alone or in association with other substances. Benzodiazepines (BDZs) are non toxic in a wide range of doses but the incidence of intoxication with them including abuse and attempts to suicide are not rare (Hood et al., 2014).

Diazepam is a long-acting, medium-potency BZD that is used as an anticonvulsant and for anxiolysis, sedation, and myorelaxation (Fox et al., 2011). It is one of group of Benzodiazepines that is likely to be associated with abuse (Longo and Johnson, 2000). A number of compounds have been reported to cause cell necrosis, or cell death. The P53 tumor suppressor protein plays a central role in cell cycle arrest and apoptosis (Polyak et al., 1997). Normally, several negative regulatory mechanisms that control P53 function was reported (Chipuk et al., 2005)

In the present study tramadol was chosen because it became nowadays one of the most abused drugs, as an alternative of narcotics due to difficulty of getting the later. Other drugs were found to be used in combination with tramadol, among which benzodiazepine was most commonly used.

\section{Aim of the work}

The aim of the current study was to investigate the effects of tramadol, diazepam, and their combination dependence on some biochemical parameters, histological and immunohistochemical changes in the brain of rats.

\section{Material and Methods}

\section{Animals}

Forty adult male albino rats of an average weight (180$200 \mathrm{~g}$ ) were obtained from the breeding animal house in Menoufia governorate. They were kept under good hygienic conditions and maintained at normal room temperature. The rat diet included standard animal food and tap water.

\section{Drugs}

1) Tramadol hydrochloride: It is pure powder. It was obtained from Sigma Company for Pharmaceutical \& Chemicals, Quesna. Egypt.

2) Diazepam: It is pure powder. It was obtained from Nile Company for Pharmaceutical \& Chemicals, Cairo. Egypt.

\section{Experimental design and treatment of animals}

Animal experiments were carried out ethically following the guidelines set by Ethical Committee of Faculty of Medicine, Menoufia University. The animals were divided randomly into four equal groups of 10 animals each.

Group I: The control group was administered $1 \mathrm{ml}$ normal saline $(0.9 \% \mathrm{NaCl})$ once by oral tube (a process called gavage) (Stine and Brown, 2006) during the entire experiment for one month.

\section{Group II: (Tramadol dependent)}

Animals were given tramadol in gradually increasing doses until they reached the dependent dose in one month.

Dependence was induced by giving the therapeutic dose of tramadol which was calculated according to Paget's equation (Paget and Barnes, 1964). The therapeutic dose for rat weighting $200 \mathrm{gm}=18 / 1000 \mathrm{x}$ adult human therapeutic dose $(400 \mathrm{mg})=7.2 \mathrm{mg}$. (Khandave et al., 2010). Then the dose was gradually increased by adding the initial calculated therapeutic dose every three days till the end of the month (ElSeidy, 2005). The calculated tramadol hydrochloride doses were delivered in $1 \mathrm{ml}$ normal saline $(0.9 \% \mathrm{NaCl})$ once and given to each animal by a gavage process) (Stine and Brown, 2006)

\section{Group III: (Diazepam dependent)}

Rats were received diazepam in gradually increasing doses until it reached the dependent dose in one month. Dependence was induced by giving the maximal therapeutic dose of diazepam to start with it, which was calculated according to Paget's equation (Paget and Barnes, 1964). The therapeutic dose for rat weighting $200 \mathrm{gm}=18 / 1000 \mathrm{x}$ adult human therapeutic daily dose (40 mg) (Crowell and Murray, 2008) $=0.72 \mathrm{mg}$. Then the dose was gradually increased by adding the initial calculated therapeutic dose every three days till the end of the month (El-Seidy, 2005). The calculated diazepam doses were delivered as suspension in $1 \mathrm{ml}$ normal saline $(0.9 \% \mathrm{NaCl})$ once and given by gavage process to each animal (Stine and Brown, 2006).

\section{Group IV: (Tramadol and Diazepam dependent)}

This group received combined therapeutic oral dose of tramadol $=7.2 \mathrm{mg}$ and diazepam $=0.72 \mathrm{mg}$ in the start. Then the dose was gradually increased by adding the initial calculated therapeutic doses every three days till the end of the month (El-Seidy, 2005). The combined drugs were administered to each animal by gavage process (Stine and Brown, 2006).

\section{Blood samples}

Blood samples were collected at the end of the experiment (one month) from venous plexus localized in the orbit behind the eye ball (retro-orbital plexus) using heparinized capillary tube and was allowed to percolate along the wall of the centrifuge tube to prevent risk of hemolysis (Halpern and Ceaune, 2000).

\section{Biochemical assay}

Serum Cortisol level was determined by using enzyme linked immunosorbant assay (ELISA) kits according to method of Arakawa et al., (1979).

Chemicals for brain cholinesterase (CHE) level: Cholinesterase kits supplied by Diamond Company for Pharmaceutical \& Chemicals, Cairo. Egypt. The tissue (brain) was weighted approximately $20 \mathrm{mg}$. $1 \mathrm{ml}$. of phosphate buffer solution ( $\mathrm{pH} 8.0,0.1 \mathrm{M}$ ) was added to the sample. The mixture was homogenized using the manual glass homogenizer. The homogenate was centrifuged at $3000 \mathrm{rpm}$ and the supernatant fluid was 
collected for measuring cholinesterase enzyme level. The cholinesterase activity was measured by spectrophotometric method described by Ellman et al., (1961).

\section{Histological study}

After animal dissection at the end of one month, the extracted brain was immediately immersed in $10 \%$ buffered formalin fixative for 48 hours, then the brain was trimmed then sent to the histology laboratory and stained with Haematoxylin \& Eosien (H\&E) and Periodic Acid Schiff (PAS) stains (Stevens and Wilson, 1996).

\section{Immunohistochemical study}

Brain sections were placed on poly-lysine coated clean slides and stained with anti-P53 according to the method of Joyner and Wall, (2008).

\section{Statistical Analysis}

Data was organized, tabulated and statistically analyzed using Statistical Package for Social Science (SPSS) version 16 for Windows software system. For quantitative data, the mean and standard deviation were calculated. The difference between two means was statistically analyzed using student (t) test. For comparison of means of more than two groups using (F) test. Statistical significance was taken at $\mathrm{p}<0.05$ (Jennifer and Belinda, 2005).

\section{Results}

\section{Biochemical study}

Table (1): Reveals that the serum cortisol level was highly significantly decreased in tramadol dependent group as compared to the control group ( $\mathrm{P}$ value $=$ $<0.001)$.

Serum cortisol level was not significantly changed in diazepam dependent group as compared to the control group as shown in table (2).

Table (3): Shows highly significant decrease in the serum cortisol level in the combined drugs (tramadol and diazepam) dependent group as compared to the tramadol or diazepam dependent groups ( $\mathrm{P}$ value $<0.001)$.

Table (4): Shows no significant deference between tramadol dependent group and control group as regard to brain cholinesterase level where $\mathrm{P}>0.05$.

Table (5): Shows no significant deference between diazepam dependent group and control group as regard to brain cholinesterase level as $\mathrm{P}>0.05$.
Brain cholinesterase level was not significantly different between all experimental groups (tramadol dependent, diazepam dependent and tramadol and diazepam dependent) where, $\mathrm{P}$ was > 0.05 as shown in table (6).

\section{Histopathology of the brain}

Light microscopic study of H\&E-stained brain sections of control group showed that the cortex of the cerebrum with normal granular and pyramidal cells with vesicular nuclei and darkly stained cytoplasm. The surrounding areas contained nerve fibers, glial cells and blood vessels (Fig.1). Normal PAS reaction (purplish-red) which appeared strong in the pyramidal cells and moderate one in the granular cells (Fig.2). Negative immune staining for P53; thus neurocytes nuclei appeared blue in color (Fig.3).

In tramadol dependent treated rats (group II), different forms of brain injury were found. The brain section showed disarrangement of its layers with neuronal degeneration, increased number of red neurons (Fig.4). Weak PAS reaction especially in the destructing neuron (Fig.5). Moderate expression of positive apoptotic cells with positive immune staining for P53. The nuclei and cytoplasm appeared brown in color (Fig. 6).

In group III (Diazepam dependent), microscopic examination of the brain specimens showed increased the vaculation in neuropil, with inflammatory cellular infiltrate, pyknotic nuclei of pyramidal cells and degenerated cells (Fig.7). Weak PAS reaction in granular cells specially degenerated ones and moderate reaction in the pyramidal cells (Fig.8). Mild expression of positive apoptotic cells with positive immune staining for P53 (brown nucleus and brown particles in the cytoplasm) (Fig. 9).

Microscopic examination of the brain specimens of group IV (Tramadol and Diazepam dependent) showed dilated vascular space, hemorrhage, gliosis of the neuropil, degenerated pyramidal cells and marked increase in number of apoptotic neurocytes (Fig. 10). Very weak (complete destruction) PAS reaction in neuronal cells (Fig. 11). Marked expression of positive apoptotic cells with positive immune staining for P53 (brown nucleus and brown particles in the cytoplasm) (Fig.

Table 1: Statistical Analysis Student 't' test of Serum Cortisol Level between Control (Group I) and Tramadol Dependent (Group II).

\begin{tabular}{|l|l|l|l|l|}
\hline & $\begin{array}{c}\text { Control } \\
\mathbf{N = 1 0}\end{array}$ & $\begin{array}{c}\text { Tramadol dependent } \\
\mathbf{N}=\mathbf{1 0}\end{array}$ & 't' & P.value \\
\cline { 2 - 3 } & Mean \pm SD & Mean \pm SD & & \\
\hline Cortisol $(\mathrm{ng} / \mathrm{ml})$ & $190.9 \pm 4.1$ & $174.5 \pm 7.3$ & 5.8 & $<0.001 * *$ \\
\hline
\end{tabular}

Table 2: Statistical Analysis Student 't' test of Serum Cortisol Level between Control (Group I) and Diazepam Dependent (Group III).

\begin{tabular}{|l|l|l|l|l|}
\hline & Control N= 10 & Diazepam dependent N= 10 & 't' & P.value \\
\cline { 2 - 3 } & Mean \pm SD & Mean \pm SD & & \\
\hline Cortisol $(\mathrm{ng} / \mathrm{ml})$ & $190.9 \pm 4.1$ & $184.3 \pm 10.8$ & 1.8 & $>0.05^{*}$ \\
\hline
\end{tabular}

$* P>0.05$ insignificant 
Table 3: Statistical Analysis (F) Test of Serum Cortisol Level in Tramadol Dependent (Group II), Diazepam Dependent (Group III) and Their Combination Dependent (Group IV).

\begin{tabular}{|l|l|l|l|l|l|}
\hline & $\begin{array}{c}\text { Tramadol dependent } \\
\mathbf{N = 1 0}\end{array}$ & $\begin{array}{c}\text { Diazepam dependent } \\
\text { N =10 }\end{array}$ & $\begin{array}{c}\text { Dependent on both drugs } \\
\mathbf{N}=\mathbf{1 0}\end{array}$ & \multirow{2}{*}{ P.value } \\
\cline { 2 - 4 } & Mean \pm SD & Mean \pm SD & Mean \pm SD & & \\
\hline Cortisol $(\mathbf{n g} / \mathbf{m l})$ & $174.5 \pm 7.3$ & $184.3 \pm 10.8$ & $153.2 \pm 14.8$ & 13.6 & $<0.001 * *$ \\
\hline
\end{tabular}

$* * P<0.001$ highly significant

Table 4: Statistical Analysis Student ' $t$ ' test of Brain CHE Level between Control (Group I) and Tramadol Dependent (Group II).

\begin{tabular}{|l|c|c|c|c|}
\hline & Control N= 10 & Tramadol dependent N=10 & 't' & P.value \\
\cline { 2 - 3 } & Mean \pm SD & Mean \pm SD & \\
\hline $\begin{array}{l}\text { Brain CHE } \\
\text { (n mol/min/mg protein })\end{array}$ & $113 \pm 5.4$ & $120.1 \pm 12.9$ & 1.5 & $>0.05^{*}$ \\
\hline
\end{tabular}

$* P>0.05$ insignificant

Table 5: Statistical Analysis Student 't' test of Brain CHE Level between Control (Group I) and Diazepam Dependent (Group III).

\begin{tabular}{|l|l|l|l|l|}
\hline & Control N= 10 & Diazepam dependent N= 10 & 't' & P.value \\
\cline { 2 - 3 } & Mean $\mathbf{4 S D}$ & Mean \pm SD & & \\
\hline $\begin{array}{l}\text { Brain CHE } \\
(\mathrm{n} \mathrm{mol} / \mathrm{min} / \mathrm{mg} \text { protein })\end{array}$ & $113 \pm 5.4$ & $115.9 \pm 3.9$ & 1.4 & $>0.05^{*}$ \\
\hline
\end{tabular}

$* P>0.05$ insignificant

Table 6: Statistical Analysis (F) Test of Brain CHE Level in Tramadol Dependent (Group II), Diazepam Dependent (Group III) and Their Combination Dependent (Group IV).

\begin{tabular}{|c|c|c|c|c|c|}
\hline \multirow[t]{2}{*}{. } & $\begin{array}{l}\text { Tramadol dependent } \\
\mathbf{N}=10\end{array}$ & $\begin{array}{l}\text { Diazepam Dependent } \\
N=10\end{array}$ & $\begin{array}{l}\text { Dependent on both drugs } \\
N=10\end{array}$ & \multirow[t]{2}{*}{ 'F' } & \multirow[t]{2}{*}{ P.value } \\
\hline & Mean \pm SD & Mean \pm SD & Mean \pm SD & & \\
\hline $\begin{array}{l}\text { Brain CHE } \\
\text { (nmol/min/mg } \\
\text { protein ) }\end{array}$ & $120.1 \pm 12.9$ & $115.9 \pm 3.9$ & $119.4 \pm 8.0$ & 0.6 & $>0.05 *$ \\
\hline
\end{tabular}

$* P>0.05$ insignificant

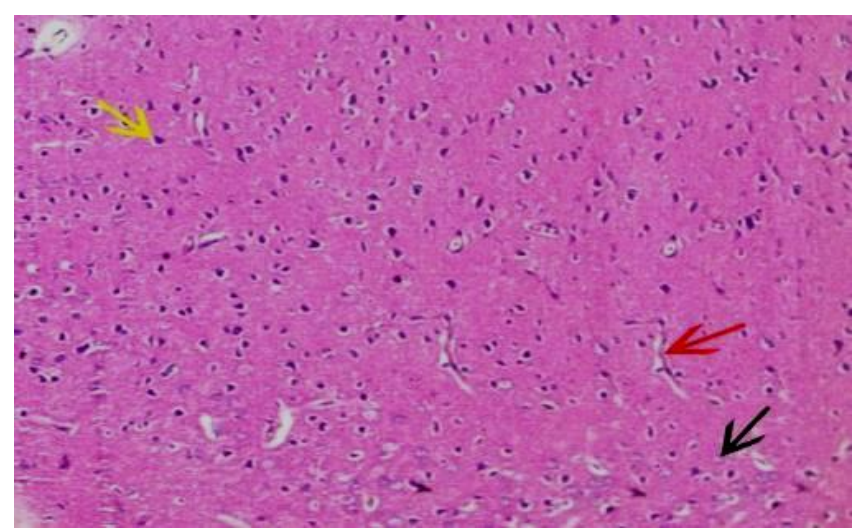

Fig.1 Photomicrograph of the control rat cerebral cortex (group I) showing normal pyramidal cells (yellow arrow), granular cells (black arrow) and perivascular space (redarrow) (H\&E, X 200).

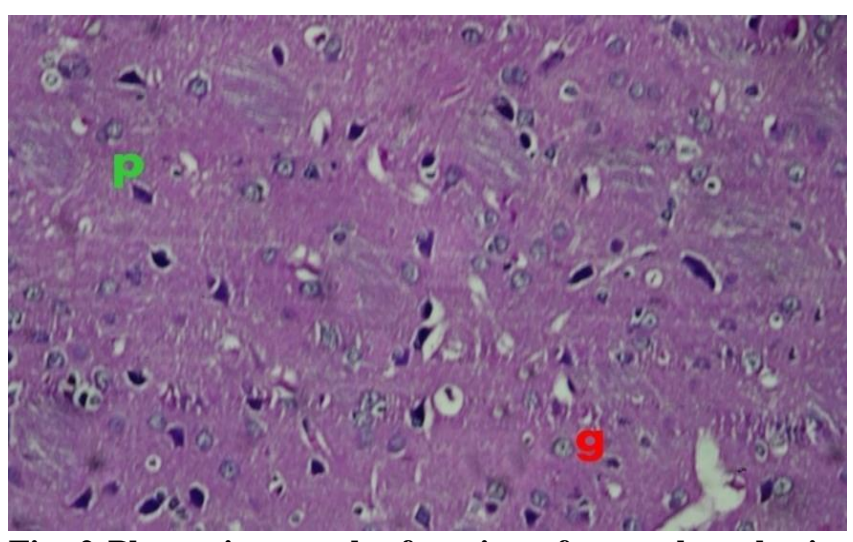

Fig. 2 Photomicrograph of section of control rat brain (group I) showing strong PAS reactions in pyramidal cells (P) and moderate reaction in granular cells (g) (PAS, $x$ 400). 


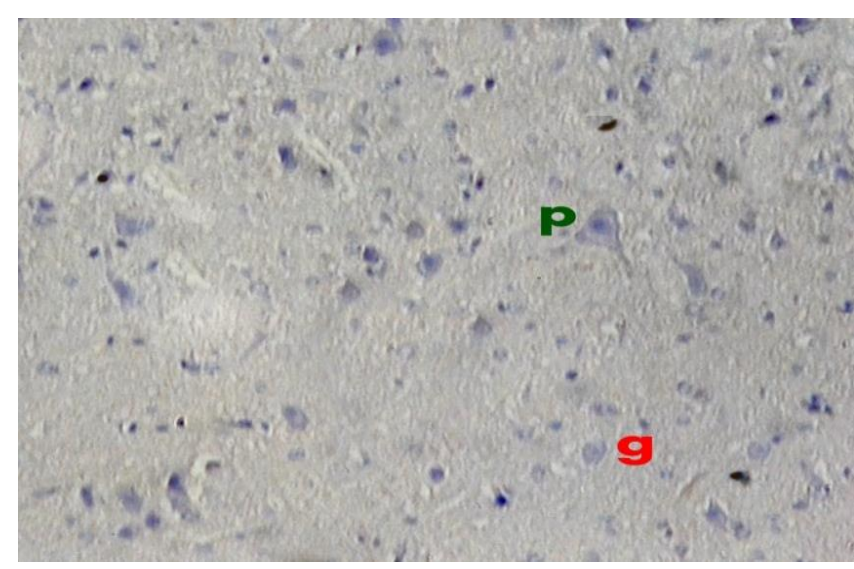

Fig. 3 Photomicrograph of a section of the brain of control rat (group I) showing negative p53 staining of neurocytes nuclei (P\& g). P53 immunstain, $x 400$.

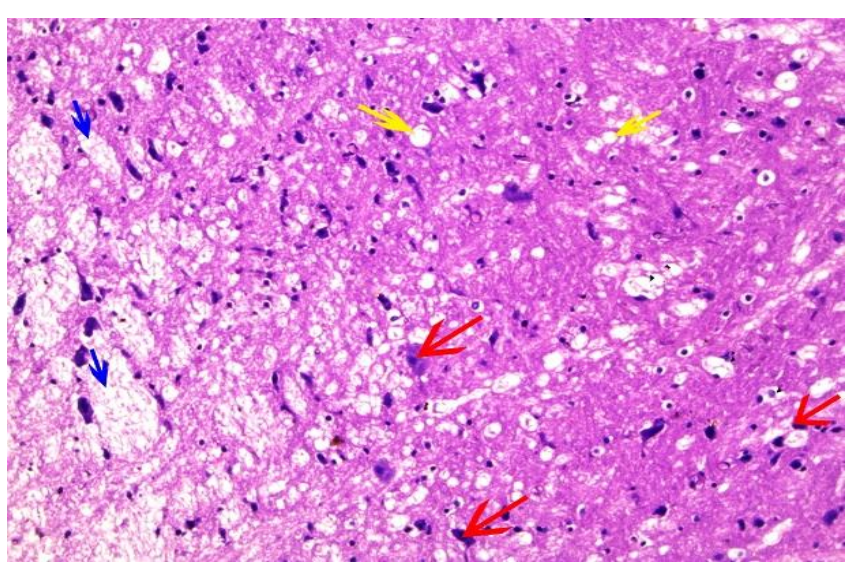

Fig. 4 Photomicrograph of a section of cerebral cortex of rat of tramadol dependent (group II) showing disarrangement of brain layers, with focal edema( blue arrows) multiple vaculation (yellow arrows) and red neuron degeneration (red arrows) (H\&E, $X$ 200).

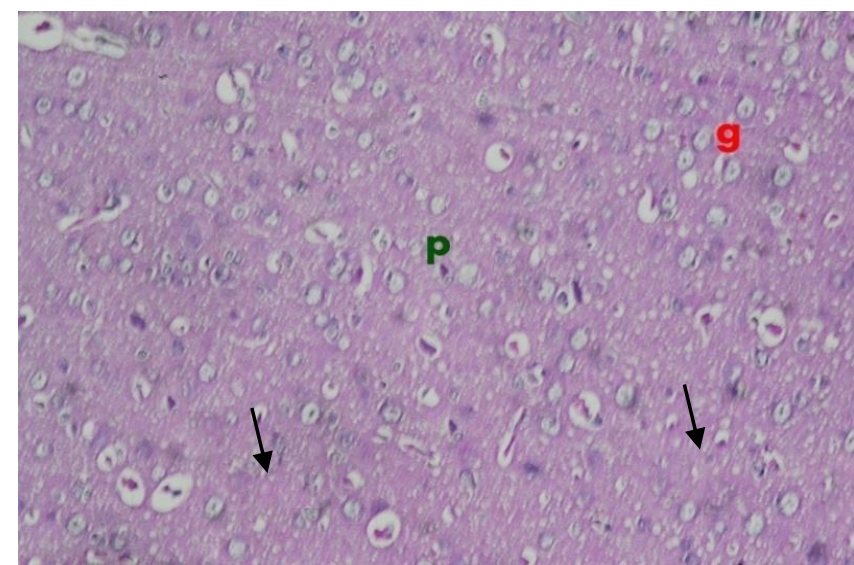

Fig 5 Photomicrograph of a section of rat brain of tramadol dependent (group II) showing weak PAS reaction (arrows) especially in destructing neuron (P\&g) cells (PAS, $x$ 400).

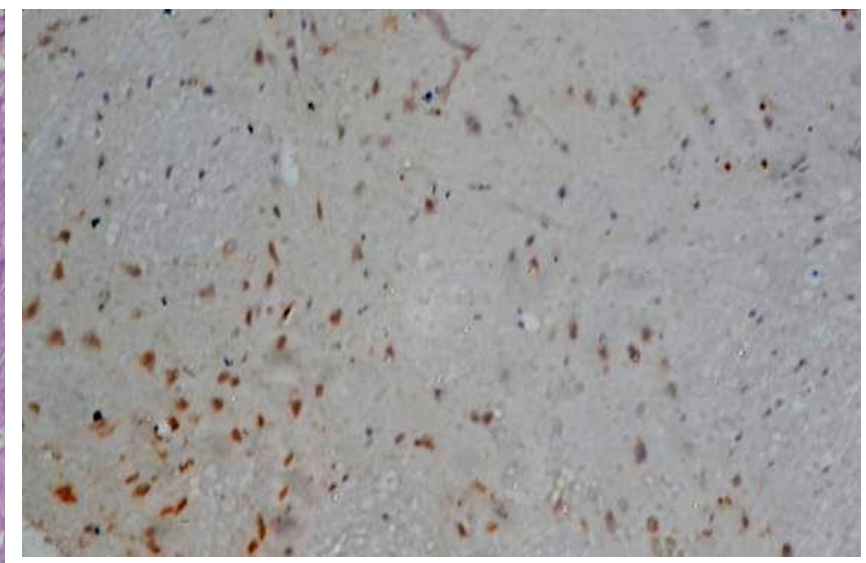

Fig. 6 Photomicrograph of brain section of tramadol dependent (group II) showing moderate expression of positive apoptotic cells with positive immune staining for P53. The nuclei and cytoplasm appeared brown in color. P53 immunostain, $x 400$.

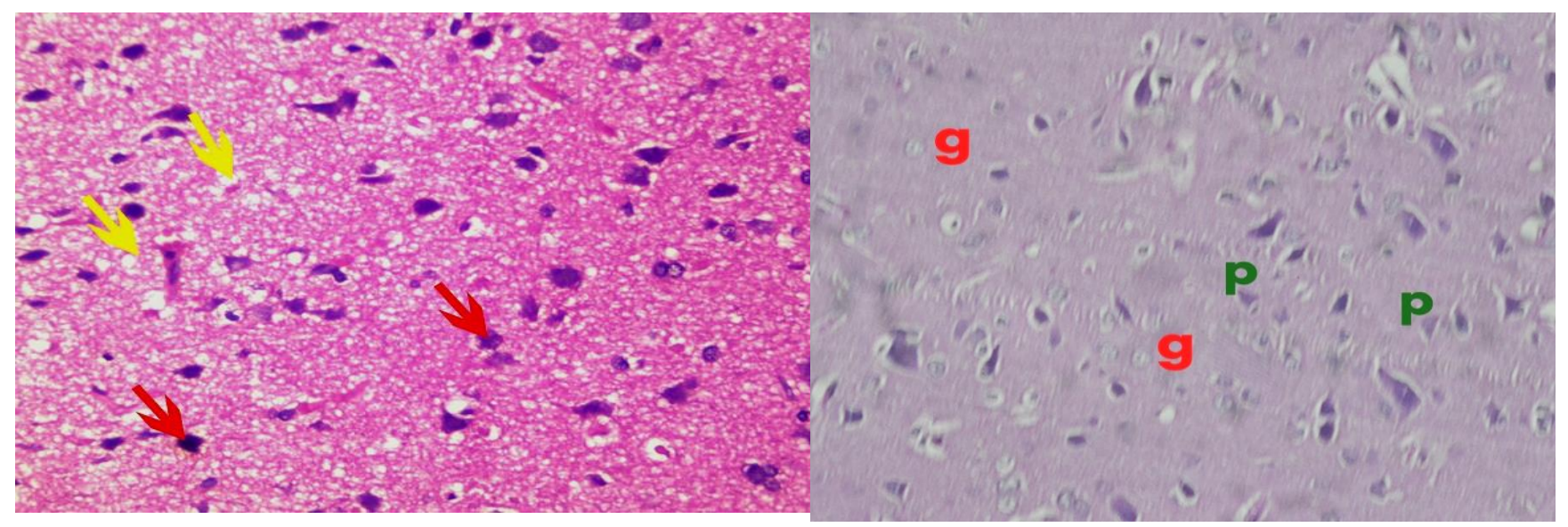

Fig. 7 Photomicrograph of brain section of diazepam dependent (group III) showing edema and vaculation of neuropil (yellow arrows), pyknotic nuclei of pyramidal cells with some degenerated cells (red arrows) (H\&E, X 400).
Fig. 8 Photomicrograph of brain section of diazepam dependent (group III) showing weak PAS reaction in granular cells specially degenerated ones (g) and moderate reaction in the pyramidal cells (p). (PAS, $x$ 400). 


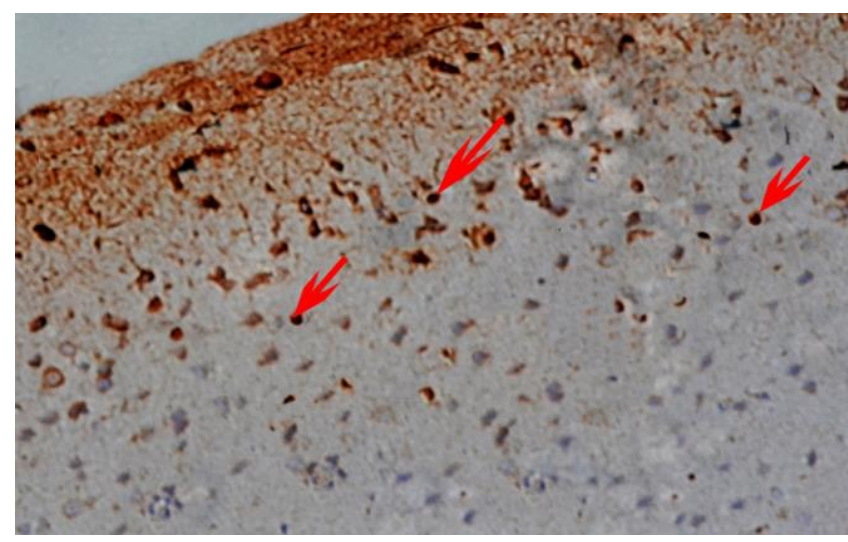

Fig. 9 Photomicrograph of brain section of diazepam dependent (group III) showing mild expression of positive apoptotic cells with positive immune staining for P53 (brown nucleus and brown particles in the cytoplasm (red arrows). P53 immunostain, $x 400$.

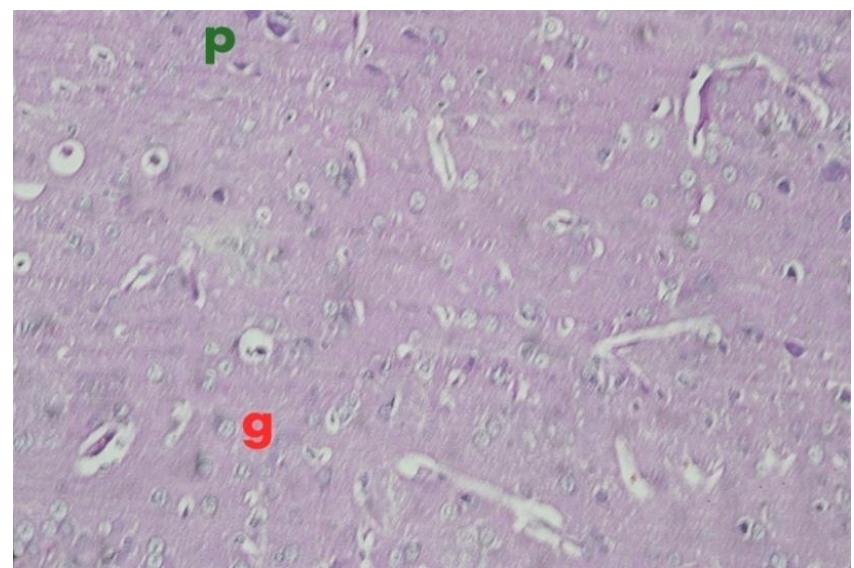

Fig. 11 Photomicrograph of brain section of tramadol and diazepam dependent (group IV) showing very weak PAS reaction in pyramidal cells $(P)$ and granular cells (g) PAS, $x 400$.

\section{Discussion}

Drug dependence is considered one of the serious problems that worry both the people and government. Nowadays opioids use and its related mortality and morbidity are one of the major concerns worldwide (Mood et al., 2014). Recently the trend of opioids use has changed because synthetic opioids such as tramadol are available too. Abuse of tramadol in Egypt and other Middle Eastern countries have reached an alarming limit (Fawzui, 2011). Among BZDs, diazepam is one of the most preferred, prescribed, and thus abused molecules (Bramness and Kornør, 2007). The aim of the present study was to determine the toxic effects of dependence of tramadol, diazepam and their combination on the brain and some biochemical parameters in albino rats.

As regard serum cortisol level it was highly significantly decreased in tramadol dependent (group II) as compared to the control (group I). This could be explained by that tramadol may lead to adrenal insufficiency due to repeated long duration of use (Chan et al., 2011). Suppression of the hypothalamicpituitary-adrenal (HPA) axis was shown in patients on

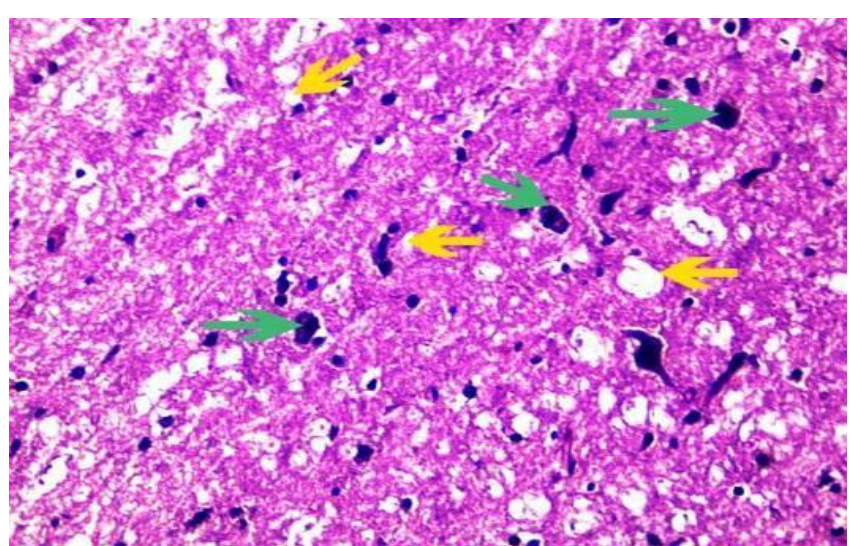

Fig. 10 Photomicrograph of brain section of tramadol and diazepam dependent (group IV) showing increased vaculation in neuropil (yellow arrows) with many apoptotic cells (green arrows). H\&E, X 400.

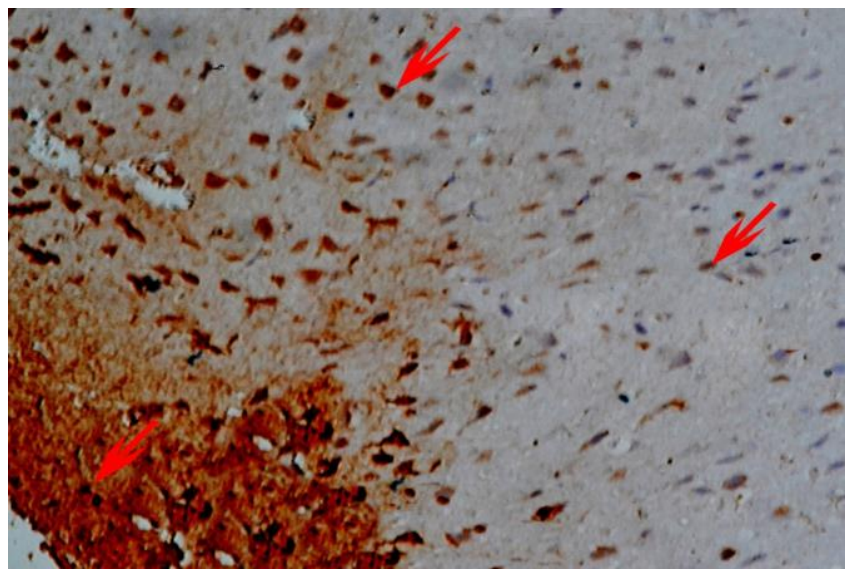

Fig. 12 Photomicrograph of brain section of tramadol and diazepam dependent (group IV) showing marked expression of positive apoptotic cells with positive immune staining for P53 (brown nucleus and brown particles in the cytoplasm) (red arrows). P53 immunostain, $x 400$.

long term intrathecal morphine_and has also been reported in three patients on chronic transdermal fentanyl, hydromorphone and methadone respectively ( Abs et al., 2000 and Oltmanns et al., 2005).

Serum cortisol level was not significantly changed in diazepam dependent group. This coincided with Sladana et al., (2007) who reported that chronic treatment of socially isolated rats with diazepam did not significantly affect stress-related adrenomedullary and adrenocortical alterations. This data wasn't agreed with Bruni et al., (1980) who stated that the repeated administration of diazepam every 24 hours for 4 days brings about a decrease in plasma cortisol level in rats.Assessing cholinergic function is considered as an important tool in neuroscience research. There are several approaches to evaluate cholinergic function indirectly, where estimation of CHE activity provides a relatively easy and valuable assessment of cholinergic function (Srikumar et al., 2004). Brain CHE level in tramadol dependent group was not changed significantly compared to the control group. This wasn't agreed with Motel et al., (2013) who 
reported that morphine or other opioid receptor agonists inhibit acetylcholinestrase (AChE) release in the brain.

Brain CHE was not significantly changed in diazepam dependent group as compared to the control group. This coincided with Shih, (1991) and Yacoub, (2007) as they reported that diazepam with different doses and at different times did not significantly affect the activity of acetylcholinestrase when compared with the control values.

In tramadol dependent treated rats, different forms of brain injury were found. The brain sections showed disarrangement of brain layers with neuronal degeneration was detected in almost all of rats, disrupted ependyma of ventricle and hypertrophied choroid plexus with papillary projections, increased number of red neuron, which are the histopathologic markers of apoptosis. Pope et al., (2005) stated that chronic repeated exposure to tramadol as a toxicants leads to accumulations of filaments that are then called neurofibrillary tangles, damage neuron can include decrease in protein synthesis and oxidative metabolism. These changes may then affect the ability of the neuron to transmit impulses and may ultimately lead to cell death. Weak PAS reaction especially in destructing neuron was detected. Similar result found in the study of Eisch et al. (2000) who concluded that chronic opiate exposure can decrease the proliferation and survival of new neurons in the mature adult brain by acting directly on the neurocytes progenitor population so decrease their proliferation and DNA synthesis via an opioid action at the $\mu$-opioid receptor. Positive expression of $\mathrm{P} 53$ was present, neurological impairments observed in drug addicts may reflect drug-induced neuronal dysfunction and neurotoxicity. The neurotoxic effects of drugs abuse are often associated with oxidative stress, mitochondrial dysfunction that lead to apoptosis and inhibition of neurogenesis (Cunha-Oliveira et al., 2007; Mohamed et al., 2013). Animals treated with repeated increasing dose of diazepam revealed an increase in edema and vaculation in neuropil, with inflammatory cellular infiltrate, some pyknotic nuclei of pyramidal cells and degenerated cells. This coops with (Ali and Zinad, 2014) who reported the occurrence of mononuclear cells aggregate around blood vessels in brain parenchyma. In the present study weak PAS reaction was found in the diazepam treated group of rats. This finding was in agreement with the study conducted by Girgis et al., (2010). Mild expression of P53 was detected in nuclei of some neuronal cells, Bittigau et al. (2002) showed that phenobarbital, diazepam and clonazepam caused widespread apoptotic neurodegeneration in the brains of rats. In tramadol and diazepam dependent group, microscopic examination of the brain specimens of the rats showed dilated vascular space, hemorrhage, gliosis of the neuropil, degenerated pyramidal cells and marked increase in number of apoptotic neurocytes. The same was proved by the study of Mohamed et al., (2013). The present study proved more toxic effect in the combined doses of tramadol and diazepam and more destruction of neuronal cells, a very weak PAS reaction was noted in the specimen of tramadol and diazepam dependent treated rats. This finding was similar to the study of Girgis et al., (2010). Marked expression of positive apoptotic cells with p53 stain in the combined abuse of tramadol and diazepam treated rats prove the histopathologic and histochemical alterations that were previously reported in this study that highlighted the fact that coadministration of both drugs enhances their toxic effects. In a similar study by Mohamed et al., (2013) who study the effect of clonazepam, tramadol and their combination on mitochondrial chain where Clonazepam alone did not show any inhibitory effect at any level; however, its combination with tramadol boosted its toxic effect especially at high doses, it seems like it acts as synergism for tramadol effect. In many types of neurons, activation of p53 apoptotic pathway may be mediated by a wide range of insulting agents such as DNA damage, ischemia/hypoxia, hypoglycemia, and excitotoxicity to oxidative stress (Musavi and Kakkar, (2003).

\section{Conclusion and recommendation}

Tramadol or diazepam dependence for long time affects the brain cells and the combination of both of them leads to more neurotoxic effect. Therefore it is recommended that tramadol or diazepam should be taken only with the prescription of doctor and self medication of these drugs may be hazardous.

\section{References}

Abdelmajeed N (2009): Diazepam-induced Oxidative Stress In rat Different Organs. Research Journal of Medicine and Medical Sciences; 4(2): 295-302.

Abs R, Verhelst J, Maeyaert J et al., (2000): Endocrine consequences of long-term intrathecal administration of opioids. The Journal of clinical endocrinology and metabolism; 85 (6): 2215-2222.

Ali AH and Zinad KH (2014): Histopathological changes and immunosuppression induce by diazepam in mice. AL-Qadisiya Journal of Vet. Med. Sci.; 13(1):59-65.

Amr M, El-Gilany A, El-Mogy A et al., (2014): Substance abuse and dependence among patients attending an emergency hospital in eastern Nile delta, Egypt Afr. J Psychiatry ;17:532-537.

Arakawa H, Maeda M and Tsuji A (1979): Chemiluminescence enzyme immunoassay of cortisol using peroxidase as label. Aanl Biochem; 97: 254-258.

Babalonisa S, Lofwalla MR, Nuzzob PA et al., (2013): Abuse liability and reinforcing efficacy of oral tramadol in humans .Drug and Alcohol Dependence 129,116 - 124 journal home page : $\underline{w w w . e l s e v i e r . c o m / l o c a t e / d r u g a l c d e p ~}$

Bittigau P, Marco S, Kerstin G et al., (2002): "Antiepileptic drugs and apoptotic neurodegeneration in the developing brain". Proceedings of the National Academy of Sciences of the United States of America ( PNAS). 99 (23): 15089- 15094. 
Bramness JG and Kornør H (2007). Benzodiazepine prescription for patients in opioid maintenance treatment in Norway. Drug Alcohol Depend. 90: 203-209.

Bruni G, Dal Pra P, Dotti M et al., (1980): Plasma acth and cortisol levels in benzodiazepine treated rats. 12(2): 163-175.

Chan S, Debono M, Rolfe C et al., (2011): Tramadolinduced Adrenal Insufficiency. Endocrine Abstracts. 25: P84.

Chipuk JE, Bouchier-Hayes L, Kuwana T et al., (2005): "PUMA couples the nuclear and cytoplasmic proapoptotic function of p53". Science. 309: 1732-1735.

Crowell S and Murray T (2008): Benzodiazepines. IN: Veterinary Psychopharmacology. ${ }^{\text {st }}$ ed. Black well.CH. 3; 34-70.

Cunha-Oliveira T, Rego AC, Garrido J et al., (2007): Street heroin induces mitochondrial dysfunction and apoptosis in rat cortical neurons. J Neurochem. 101:543-554.

Eisch, AJ, Barrot, M, Schad CA et al., (2000): "Opiates inhibit neurogenesis in the adult rat hippocumps. Proc Natl Acad Sci USA. 97(13):7579-7584.

Ellman GL, Courtney KD, Andres V et al., (1961): A new and rapid colorimetric determination of acetylcholinesterase activity. Biochemical Pharmacology, Vol. 7, pp 88-95. PergamonP ressL td, Printed in Great Britain. Environmental Toxicology and Pharmacology ;19(3): 433-446

El-Seidy AM (2005): Evaluation of different protocols for treatment of dependence. MD thesis (Clin. Toxicology) Faculty of Medicine Menoufia university.

Fawzui MM (2011): Some medicolegal aspects concerning tramadol abuse: The new Middle East youth plague 2010. An Egyptian overview. Egypt J Forensic Sci.; 9(2):99-102.

Fox C, Liu H , Kaye AD et al., (2011): Clinical Aspects of Pain Medicine and Interventional Pain Management: A Comprehensive Review. Paducah, KY: ASIP Publishing. Antianxiety agents. pp. 543-552.

Girgis N, Kamel S, Labib B et al., (2010): Cellular and DNA changes due to clonazepam abuse in brains of albino rats and role of clonidine during withdrawal period. Mansoura J. Forensic Med. Clin. Toxicol. 18:(1).

Halpern RS and Ceaune S (2000): International federation of clinical chemistry (IFCC). 145146.

Hood S, Norman A, Hince D et al., (2014): Benzodiazepine dependence and its treatment with low dose flumazenil.British Journal of Clinical Pharmacology. 77(2): 285-294.

Jennifer P and Belinda B (2005): Medical Statistics. A Guide to Data Analysis and Critical Appraisal” BMJ Books Blackwell Publishing Inc.
Joyner A and Wall N (2008): Immunohistochemistry of whole-mount mouse embryos. Cold Spring Harbor Protocols. (2): 4820.

Kessler RC, Nelson CB, McGonagle KA et al., (1996): The epidemiology of co-occurring addictive and mental disorders: Implications for prevention and service utilization. American Journal of Orthopsychiatry. 66: 17-31.

Khandave SS, Sawant SV, Joshi SS et al., (2010): Comparative bioequivalence studies of tramadol hydrochloride sustained-release 200 mg tablets. Drug Des Devel Ther. 4: 367374.

Lanier RK, Lofwall MR, Mintzer MZ et al., (2010): Physical dependence potential of daily tramadol dosing in humans. Psychopharmacol (Berl). 211(4): 457-466.

Longo L and Johnson B (2000): Addiction: Part I. Benzodiazepines-Side Effects, Abuse Risk and Alternatives. Am Fam Physician. 61(7): 2121-2128

Mohamed TM, Abdel Ghaffar HM, and El Husseiny RM (2013): Effects of tramadol, clonazepam, and their combination on brain mitochondrial complexes. Toxicol Ind Health.1-9. DOI: 10.1177/0748233713491814. http://tih.sagepub.com/content/early/2013/07/ 08/0748233713491814

Mood EN, Ozcan D, Sabzghabaee AM et al., (2014): Does naloxone prevent seizure in tramadol intoxicated patients?. Int J Prev Med. 5:302-7.

Motel WC, Coop A, and Cunningham CW (2013): Cholinergic Modulation by Opioid Receptor Ligands: Potential Application to Alzheimer's Disease. Mini Rev Med Chem. 13(3): 456466.

Musavi S and Kakkar P (2003): Effect of diazepam treatment and its withdrawal on pro/antioxidative processes in rat brain. Mol Cell Biochem. 245(1-2):51-6.

Oltmanns KM, Fehm HL, and Peters A (2005): Chronic fentanyl application induces adrenocortical insufficiency. Journal of internal medicine. 257 (5): 478-480.

Paget GE and Barnes JM (1964): Interspecies dosage conversion schem in evaluation of results and quantitative application in different species. In: Evaluation of Drug Activities: Pharmacometrics.Laurence DR and Bacharach AL (Eds.), Vol. 1,Academic press, London, New York

Polyak K, Xia Y, Zweier JL et al., (1997): "A model for p53-induced apoptosis". Nature. 389: 300305.

Pope C, Karanth S and Liu J (2005): Pharmacology and toxicology of cholinesterase inhibitors: uses and misuses of a common mechanism of action.

Shadnia S, Soltaninejad K, Heydari K et al., (2008): Tramadol intoxication: a review of 114 cases. Hum Exp Toxicol. 27(3):201-205. 
Shih TM (1991): Cholinergic action of diazepam and atropine in soman poisoning. Brain Res Bull. 26: 565-573.

Sladana D, Natasa S, Ljubica G et al., (2007): Behavioural and endocrine responses of socially isolated rats to long-term diazepam treatment. Acta Veterinaria (Beograd). 57(4): 291-302.

Srikumar BN, Ramkumar K, Raju TR et al., (2004): Assay of acetylcholinesterase activity in the brain. Brain and Behavior. Raju TR, Kutty BM, Sathyaprabha TN and Shanakranarayana Rao BS (eds.), National Institute of Mental Health and Neuro Sciences, Bangalore, India. 142-144.

Stevens A and Wilson IG (1996): The haematoxylin and eosin. In: Bancroft JD, Stevens A, editors. Theory and practice of histological techniques. 4th ed. New York: Churchill Livingstone. pp. 99-112

Stine KE and Brown TM (2006): Neurotoxicology (chapters 1,9,10, 11, and 12. Principles of toxicology. 2nd ed. London: Taylor and Francis

Wang Sh-Q, Li Ch-Sh and Song YG (2009): Multiply organ dysfunction syndrome due to tramadol intoxication alone. Am J Emerg Med. 27(7):903.e5-7.

Yacoub LK (2007): Short-term effect of chlorpromazine and diazepam on blood plasma acetylcholinesterase activity in chicks. Iraqi Journal of Veterinary Sciences. 21(1): 11-14.

\section{الملخص العربي}

\section{تأثيرات الإعتماد على الترامادول, الديازيبام وكلاهما معا على مخ الجرذان البيضاء: دراسة كميائية حيوية وهستولوجية و هستوكيميائية مناعية}

\section{سامي مصطفى بلوي و سامي عبد الهادي حماد و صفاء عبد الظاهر امين و عزة وجيه زناتي و ريهام حسن محمد 1 و هيام عبد السميع عياد 2}

$$
\begin{aligned}
& \text { المقدمة: يعتبر الترامادول في هذه الآونة اكثر الادوية شيوعا وسوء استخداما, ويستخدم بمدى واسع مع البنزوديازبين . }
\end{aligned}
$$

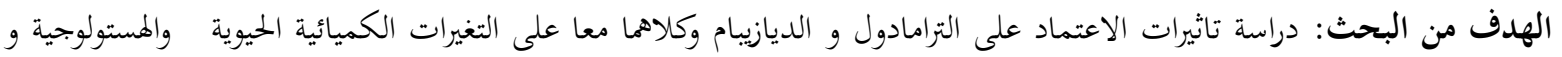

$$
\begin{aligned}
& \text { الهستوكيميائية مناعية في مخ الجرذان البيضاء. }
\end{aligned}
$$

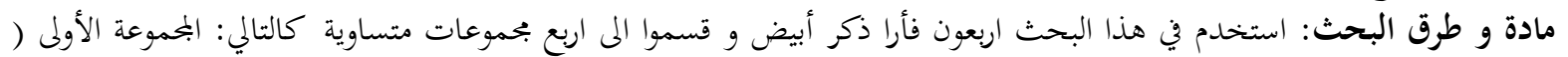

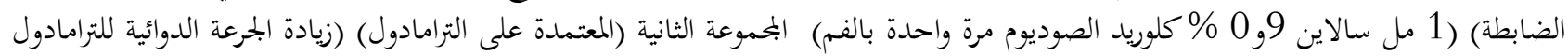

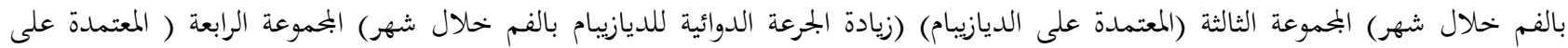

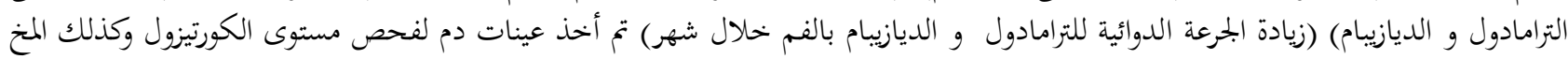

$$
\begin{aligned}
& \text { للفحص الكميائي الحيوي والهستولوجي و الهستوكيميائي مناعي. }
\end{aligned}
$$

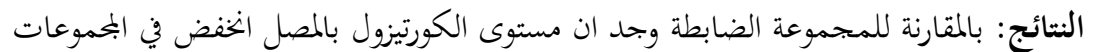

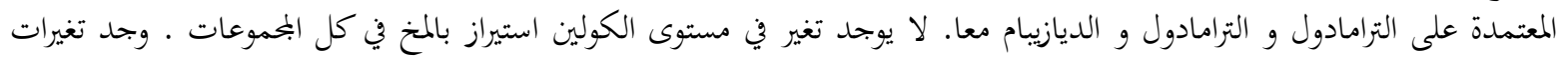

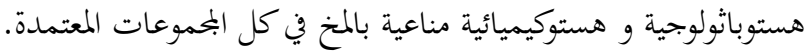

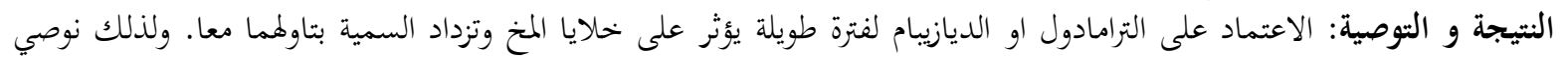

$$
\begin{aligned}
& \text { بان يتم اعطاء الترامادول او الديازيبام بوصفه عن طريق الطبيب , وتناول هذه الادوية ذاتيا فيه مخاطرة. } \\
& 1 \text { قسم الطب الثرعي والسموم الإكلينيكية - كلية الطب - جامعة المنوفية. } \\
& 2 \text { قسم الطب الباثولوجي - كلية الطب - جامعة المنوفية }
\end{aligned}
$$

